\title{
ROOT PROTRUSION IN QUALITY EVALUATION OF CHIA SEEDS ${ }^{1}$
}

\author{
IZABELA CRISTINA DE OLIVEIRA ${ }^{2}$, CARLOS HENRIQUE QUEIROZ REGO ${ }^{2}$, FERNANDA BRITO CARDOSO ${ }^{2}$,

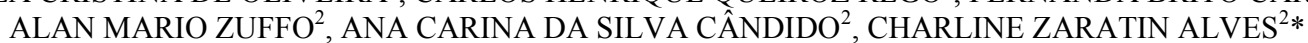

\begin{abstract}
The root protrusion test is a vigor test based on the principle that seeds with high vigor emit the primary root faster than less vigorous ones. Chia is a plant propagated by seeds and it is studied owing to its health benefits, but there is little technical information known about its culture. The objective of this work was to adapt the methodology of the root protrusion test to determine the vigor of chia seed lots. Five chia seed lots were submitted to an initial quality evaluation using germination and vigor tests (first germination, emergence, and emergence speed index). The root protrusion test was performed at temperatures of 20,25 and $30{ }^{\circ} \mathrm{C}$ and evaluated every $2 \mathrm{~h}$ up to $42 \mathrm{~h}$. During the test, protrusion stability was assessed and the criterion of $2 \mathrm{~mm}$ primary root count was used. The root protrusion test at $20{ }^{\circ} \mathrm{C}$ did not distinguish the lots in the same way as emergence. At $25^{\circ} \mathrm{C}$ it was possible to classify lots after $30 \mathrm{~h}$ similarly to emergence. At $30{ }^{\circ} \mathrm{C}$, root protrusion and the separation of seed lots was accelerated. Thus, the root protrusion test conducted for $30 \mathrm{~h}$ at $25{ }^{\circ} \mathrm{C}$ has sufficient sensitivity to detect differences in vigor between chia seed lots.
\end{abstract}

Keywords: Salvia hispanica. Vigor. Primary root.

\section{PROTRUSÃO RADICULAR NA QUALIDADE DE SEMENTES DE CHIA}

RESUMO - O teste de protrusão radicular é um teste de vigor, baseando no princípio de que sementes com alto vigor emitem a raiz primária mais rápido em comparação com as menos vigorosas. A chia é uma planta propagada por sementes, sendo motivo de pesquisa pelos seus benefícios a saúde, mas com poucas informações técnicas sobre a cultura. O objetivo do trabalho foi adequar à metodologia do teste de protrusão radicular para determinação do vigor de lotes de sementes de chia. Utilizou-se cinco lotes de sementes de chia, submetidos à avaliação da qualidade inicial por meio dos testes de germinação e vigor (primeira contagem de germinação, emergência e índice de velocidade de emergência). $\mathrm{O}$ teste de protrusão radicular foi realizado nas temperaturas de 20,25 e $30^{\circ} \mathrm{C}$, e avaliado a cada duas horas até 42 horas, onde se obteve a estabilidade da protrusão, e sendo utilizado o critério de contagem de $2 \mathrm{~mm}$ de raiz primária. O teste de protrusão radicular na temperatura de 20 ${ }^{\circ} \mathrm{C}$ não distinguiu os lotes semelhantes à emergência. A $25{ }^{\circ} \mathrm{C}$, foi possível classificar os lotes de forma semelhante à emergência após 30 horas. A temperatura de $30{ }^{\circ} \mathrm{C}$ foi eficiente na aceleração da protrusão radicular e separação dos lotes de sementes. $\mathrm{O}$ teste de protrusão radicular é sensível para detectar diferenças de vigor entre os lotes de sementes de chia, devendo ser conduzido por 30 horas a $25^{\circ} \mathrm{C}$.

Palavras-chave: Salvia hispanica. Vigor. Raiz primária.

\footnotetext{
*Corresponding author

${ }^{1}$ Received for publication in 08/08/2018; accepted in 10/01/2018.

${ }^{2}$ Department of Agronomy, Universidade Federal de Mato Grosso do Sul, Chapadão do Sul, MS, Brazil; izabelamarangon@gmail.com ORCID: 0000-0002-4666-801X, carlosqueirozagro@gmail.com - ORCID: 0000-0001-5483-9264, fernandabcardoso@hotmail.com ORCID: 0000-0002-0370-261X, alan.zuffo@ufms.br-ORCID: 0000-0001-9704-5325, ana.candido@ufms.br-ORCID: 0000-0002-92304807, charline.alves@ufms.br - ORCID: 0000-0001-6228-078X.
} 


\section{INTRODUCTION}

Chia (Salvia hispanica L.) is a plant belonging to the Lamiaceae family and has been used since pre-Columbian times as a staple food by Central American civilizations (AYERZA; COATES, 2011). It is propagated through seeds and has been the subject of scientific research owing to its health benefits, high protein content, and nutritional value (SANDOVAL-OLIVEROS; PAREDES-LÓPES, 2013).

In Brazil, chia cultivation has shown good results in western Paraná and northwest of Rio Grande do Sul, despite the lack of technical information about the crop (MIGLIAVACCA et al., 2014). With the emergence of new commercial areas of cultivation, information on the emergence and establishment of the crop would facilitate management and reduce risks to invested capital (HOFS et al., 2004).

The germination test has limitations in its ability to differentiate lots and there is a delay in obtaining the results. Consequently, more reliable and faster tests of vigor have been developed, which expedite decisions (CUSTÓDIO, 2005). The relationship between vigor tests and establishment of field seedlings is frequently used to assess the validity of the laboratory results (LEAL et al., 2012).

Primary root protrusion or emission is part of the seed germination process, occurring after water absorption and resumption of physiological events (NONOGAKI, 2006). It can be identified by the elongation of the embryonic axis (BEWLEY; BLACK, 1982) and its rate of occurrence depends on the characteristics of each species and the chemical composition and permeability of the integument (ALBUQUERQUE et al., 2009). The root protrusion test is a vigor test, based on the principle that seeds with higher vigor emit the primary root faster than less vigorous ones (PEREIRA et al., 2012).

In a study by Wrasse et al. (2009) using rice seeds (Oryza sativa), the root protrusion test was able to classify lots according to their physiological quality. A similar result was obtained by Rocha et al. (2016), in which the root protrusion test exhibited sensitivity in the detection of differences in moringa seed lots (Moringa oleifera Lam.). MartinelliSeneme et al. (2004) also observed that the root protrusion test was promising in the differentiation of pelleted tomato seed lots (Solanum lycopersicum).

Nowadays, there is a growing tendency to develop tests that can quickly measure the viability and vigor of seed lots, eliminating human subjectivity and allowing quick decision making in the planning and planting of the crop. Thus, the objective of this work was to adapt the methodology of the root protrusion test to determine the vigor of chia seed lots.

\section{MATERIAL AND METHODS}

Five lots of commercially available chia seeds were used. Their water content was determined and an initial quality evaluation performed using germination, first germination count, emergence, and emergence speed index tests. The statistical design was completely randomized, with five treatments and four replicates. The greenhouse method was used to determine the water content of the lots at 105 $\pm 3{ }^{\circ} \mathrm{C}$ for $24 \mathrm{~h}$, using two replicates each containing $2 \mathrm{~g}$ (BRASIL, 2009).

The germination test was carried out with four replicates of 50 seeds in a transparent gerbox $(11.5 \times 11.5 \times 3.5 \mathrm{~cm})$ containing a blotting paper sheet moistened with distilled water, which had 2.5 times the mass of the non-hydrated paper, and seeds were allowed to germinate at a constant temperature of $25 \pm 2{ }^{\circ} \mathrm{C}$ (BRASIL, 2009). The evaluation was performed seven days after the test was begun and the results were expressed as percentage of normal seedlings. The first germination count was performed together with the germination test when the percentage of normal seedlings obtained four days after test commencement was computed. The fourth day was chosen based on reports by Possenti et al. (2016); Stefanello et al. (2015), who stated that the germination of chia seeds showed little difference between seven and fourteen days, already reaching high values with seven days.

For the emergence test, four replicates of 50 seeds per treatment were used, seeded in trays of expanded polystyrene with 200 cells containing commercial substrate and conditioned in a greenhouse with twice daily watering. The counting was performed at seven days and the results were expressed as percentage of normal emerged seedlings. Together with the emergence test, the emergence speed index was evaluated according to the formula proposed by Maguire (1962).

In the root protrusion test, 50 seeds were placed in each gerbox with blotting paper previously moistened with $5 \mathrm{~mL}$ of distilled water. The boxes were conditioned in germination at temperatures of 20,25 and $30{ }^{\circ} \mathrm{C}$. The evaluations were performed every $2 \mathrm{~h}$ up to $42 \mathrm{~h}$, with protrusion stability being assessed and the protrusion of $2 \mathrm{~mm}$ of primary root used as a counting criterion.

Two evaluation criteria were adopted: root protrusion emission precocity index (RPEPI) and percentage of seeds that emitted primary root (EPR). The RPEPI was calculated using the formula proposed by Maguire (1962): RPEPI $=\mathrm{E} 1 / \mathrm{N} 1+\mathrm{E} 2 /$ $\mathrm{N} 2+\ldots \mathrm{En} / \mathrm{Nn}$ (where: RPEPI $=$ root protrusion emission precocity index; E1, E2,... En = number of seeds that emitted the primary root $(>2 \mathrm{~mm})$ in the first, second and $\mathrm{n}^{\text {th }}$ counts; $\mathrm{N} 1, \mathrm{~N} 2, \ldots \mathrm{Nn}=$ period in hours that the first, second and $\mathrm{n}^{\text {th }}$ counts were performed). Primary root emission (EPR) was measured as the number of seeds that emitted the 
primary root $(>2 \mathrm{~mm})$ every $2 \mathrm{~h}$ from the commencement of the test up to $42 \mathrm{~h}$.

Data were checked to assess normality and homogeneity and then evaluated using analysis of variance; means were compared using the ScottKnott test at 5\% probability, employing the statistical program Sisvar.

\section{RESULTS AND DISCUSSION}

The difference in moisture content between chia seed lots was one percentage point at most (Table 1). This was considered acceptable because it was less than the maximum allowed variation of two percentage points, according to Marcos-Filho (2015). The germination test indicated lots 1,2 , and 3 as the ones with the highest germinative potential, while lots 4 and 5 had low potential (Table 1). In the first germination count test, lot 1 was determined to have the highest vigor; lots 3,4 and 5 were the least vigorous, and lot 2 was considered to have intermediate or medium vigor (Table 1).

Table 1. Level of moisture, germination (GERM), first germination count (FGC), seedling emergence (EMER) and emergence speed index (ESI) of five lots of chia seeds.

\begin{tabular}{cccccc}
\hline LOTS & MOISTURE (\%) & $\begin{array}{c}\text { GERM } \\
(\%)\end{array}$ & $\begin{array}{c}\text { FGC } \\
(\%)\end{array}$ & $\begin{array}{c}\text { EMER } \\
(\%)\end{array}$ & $\begin{array}{c}\text { ESI } \\
-\end{array}$ \\
\hline 1 & 8.22 & $86 \mathrm{a}$ & $57 \mathrm{a}$ & $51 \mathrm{~b}$ & $0.61 \mathrm{~b}$ \\
2 & 8.64 & $88 \mathrm{a}$ & $42 \mathrm{~b}$ & $81 \mathrm{a}$ & $1.00 \mathrm{a}$ \\
3 & 9.09 & $87 \mathrm{a}$ & $31 \mathrm{c}$ & $83 \mathrm{a}$ & $1.14 \mathrm{a}$ \\
4 & 9.11 & $72 \mathrm{~b}$ & $25 \mathrm{c}$ & $56 \mathrm{~b}$ & $0.82 \mathrm{~b}$ \\
5 & 9.22 & $72 \mathrm{~b}$ & $19 \mathrm{c}$ & $52 \mathrm{~b}$ & $0.78 \mathrm{~b}$ \\
\hline $\mathrm{F}$ & - & $15.90^{*}$ & $20.62^{*}$ & $23.87^{*}$ & $5.63^{*}$ \\
\hline $\mathrm{CV}(\%)$ & - & 5.04 & 18.57 & 10.14 & 19.96 \\
\hline
\end{tabular}

*significant by $\mathrm{F}$ test. Means followed by the same letter in the column do not differ by Scott-Knott test at $5 \%$ probability. CV - coefficient of variation.

The emergence (EMER) and emergence speed indexes (ESI) highlighted lots 2 and 3 as the most vigorous, while lots 1,4 and 5 were considered to have less vigor (Table 1). The physiological potential of the seeds is a result of the interaction of genetic, physiological, and health factors. Germination and vigor information obtained in the laboratory should allow for the comparison of seed lots and evaluation of their probability of success after sowing. Evaluating to what extent the potential identified in the laboratory manifests in the field will provide information on the efficiency of the method used to compare lots in the laboratory (MARCOSFILHO, 2015).
The root protrusion test performed at $20^{\circ} \mathrm{C}$ (Table 2) did not distinguish the lots in the same way as emergence and should not be used to classify the vigor of chia seed lots. Stratification of the lots at 20 ${ }^{\circ} \mathrm{C}$ was possible after $32 \mathrm{~h}$ and indicated that lot 2 was the most vigorous, while lot 5 was the least vigorous and lots 1,3 , and 4 showed intermediate values for vigor (Table 2). Conducting the test at a temperature of $20{ }^{\circ} \mathrm{C}$ resulted in an increase in the time required for root protrusion, explained by the fact that temperature influences both germination percentage and speed, and interferes with water absorption and chemical reactions (CARVALHO; NAKAGAWA, 2012).

Table 2. Percentage of root protrusion at $20^{\circ} \mathrm{C}$ in five lots of chia seeds.

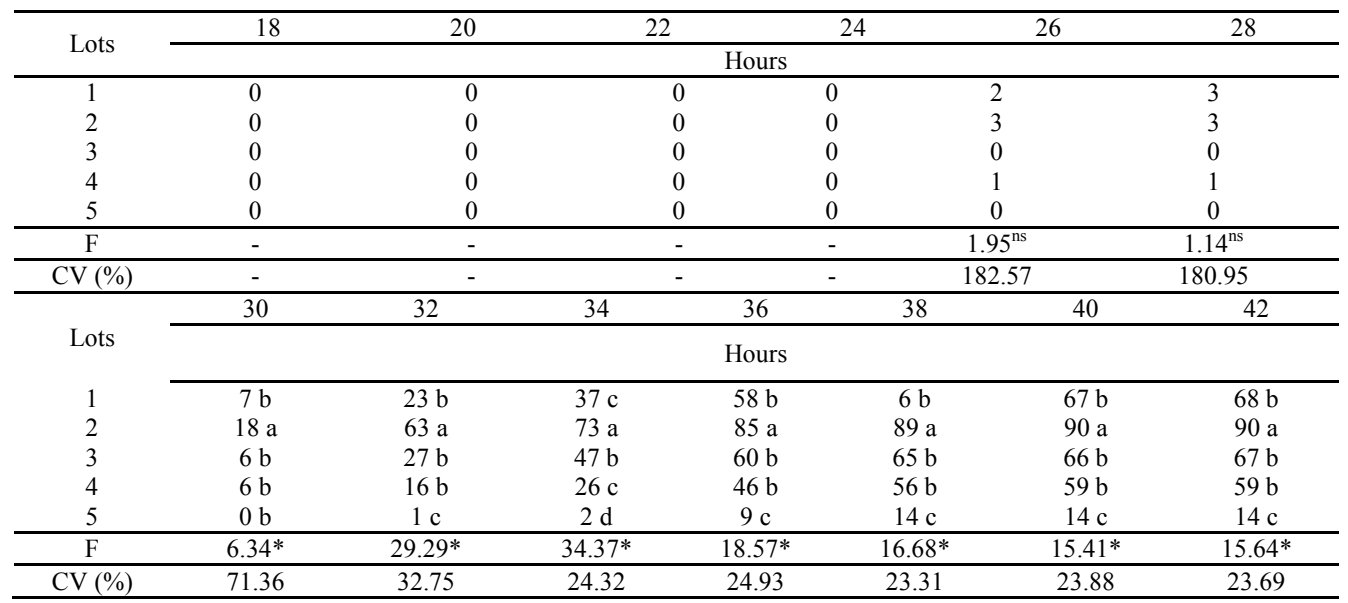

${ }^{n s}$ not significant at $5 \%$ probability. * significant by $\mathrm{F}$ test. Means followed by the same letter in the column do not differ by Scott-Knott's test at 5\% probability. CV - coefficient of variation. 
At $25{ }^{\circ} \mathrm{C}$ (Table 3 ) it was possible to classify lots after $30 \mathrm{~h}$ similarly to emergence; lots 2 and 3 were the most vigorous and lots 1, 4, and 5 had less vigor. Martins et al. (2002) alsoin broccoli seeds, demonstrated that it was possible to differentiate broccoli seed lots by vigor using the root protrusion test at this temperature. According to Toledo et al. (1999), using the primary root emission test, it was possible to detect differences between lots of maize seeds, when this one has differences in the physiological quality.

Table 3. Percentage of root protrusion at $25^{\circ} \mathrm{C}$ in five lots of chia seeds.

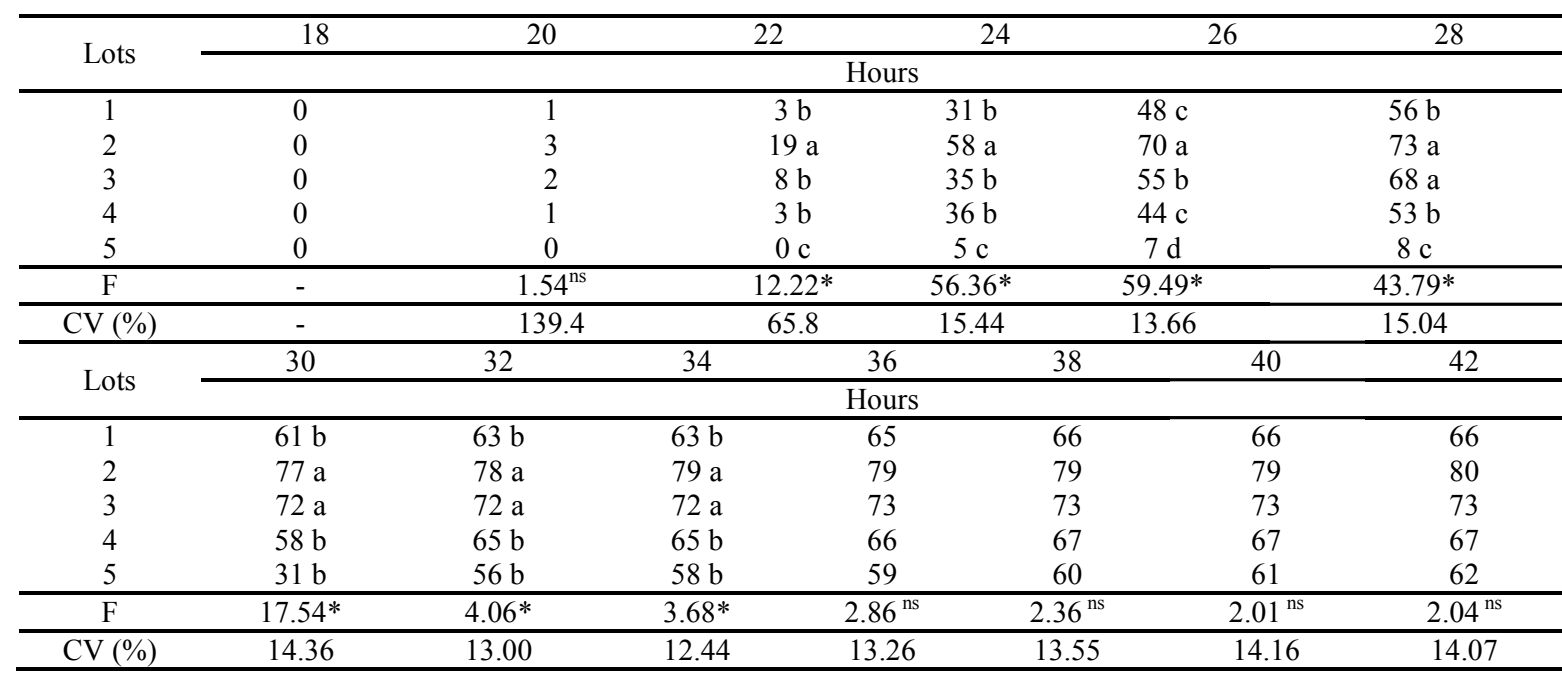

${ }^{\mathrm{ns}}$ not significant at $5 \%$ probability. *significant by $\mathrm{F}$ test. Means followed by the same letter in the column do not differ by Scott-Knott's test at 5\% probability. CV - coefficient of variation.

The temperature of $30^{\circ} \mathrm{C}$ (Table 4) efficiently accelerated root protrusion and separation of seed lots. After $18 \mathrm{~h}$, it was already possible to observe that lots 1 and 2 were the most vigorous, and lots 3, 4 , and 5 presented less vigor (Table 4). However, the results were not consistent with those of the emergence test, in which different lots were identified as having greater and less vigor. According to Bewley and Black (1994), seeds have the ability to germinate over the temperature range characteristic of the species, and since vigor is directly proportional to the degree of seed survival, increasing the temperature can cause an increase in root protrusion for different evaluation periods.

Table 4. Percentage of root protrusion at $30^{\circ} \mathrm{C}$ in five lots of chia seeds.

\begin{tabular}{|c|c|c|c|c|c|c|c|}
\hline \multirow{2}{*}{ Lots } & 18 & 20 & & 22 & 24 & 26 & 28 \\
\hline & \multicolumn{7}{|c|}{ Hours } \\
\hline 1 & $43 \mathrm{a}$ & $54 b$ & & $68 \mathrm{~b}$ & $73 \mathrm{~b}$ & $74 b$ & $74 b$ \\
\hline 2 & $52 \mathrm{a}$ & $68 \mathrm{a}$ & & $80 \mathrm{a}$ & $85 \mathrm{a}$ & $85 \mathrm{a}$ & $86 \mathrm{a}$ \\
\hline 3 & $24 b$ & $35 \mathrm{c}$ & & $50 \mathrm{c}$ & $62 \mathrm{c}$ & $63 \mathrm{c}$ & $64 \mathrm{c}$ \\
\hline 4 & $16 \mathrm{~b}$ & $25 \mathrm{c}$ & & $48 \mathrm{c}$ & $61 \mathrm{c}$ & $64 \mathrm{c}$ & $68 \mathrm{c}$ \\
\hline 5 & $0 \mathrm{c}$ & $6 \mathrm{~d}$ & & $17 \mathrm{~d}$ & $41 \mathrm{~d}$ & $47 \mathrm{~d}$ & $54 \mathrm{~d}$ \\
\hline $\mathrm{F}$ & $27,03 *$ & $43.86^{*}$ & & $68.5 *$ & $24.1 *$ & $19.27 *$ & $12.95 *$ \\
\hline CV (\%) & 29.57 & 19.56 & & 11.09 & 10.38 & 9.63 & 9.63 \\
\hline \multirow{2}{*}{ Lots } & 30 & 32 & 34 & 36 & 38 & 40 & 42 \\
\hline & \multicolumn{7}{|c|}{ Hours } \\
\hline 1 & $75 b$ & $75 b$ & $76 \mathrm{~b}$ & $76 \mathrm{~b}$ & $77 \mathrm{~b}$ & $78 \mathrm{~b}$ & $78 \mathrm{~b}$ \\
\hline 2 & $87 \mathrm{a}$ & $88 \mathrm{a}$ & $88 \mathrm{a}$ & $88 \mathrm{a}$ & $89 a$ & $90 \mathrm{a}$ & $91 \mathrm{a}$ \\
\hline 3 & $65 \mathrm{c}$ & $65 \mathrm{c}$ & $67 \mathrm{~b}$ & $67 \mathrm{~b}$ & $67 \mathrm{c}$ & $67 c$ & $67 c$ \\
\hline 4 & $70 \mathrm{~b}$ & $70 \mathrm{c}$ & $70 \mathrm{~b}$ & $70 \mathrm{~b}$ & $71 \mathrm{c}$ & $71 \mathrm{c}$ & $71 \mathrm{c}$ \\
\hline 5 & $59 \mathrm{c}$ & $60 \mathrm{c}$ & $62 \mathrm{~b}$ & $63 \mathrm{~b}$ & $64 \mathrm{c}$ & $65 \mathrm{c}$ & $65 \mathrm{c}$ \\
\hline $\mathrm{F}$ & $15.82 *$ & $13.19^{*}$ & $11.29 *$ & $9.76^{*}$ & $11.04 *$ & $12.09 *$ & 13.94* \\
\hline CV $(\%)$ & 7.58 & 8.27 & 8.28 & 8.73 & 8.13 & 7.79 & 7.64 \\
\hline
\end{tabular}


However, for the root protrusion emission precocity index (RPEPI), lot 2 had the highest vigor and lot 5 had the lowest vigor at the three temperatures tested (Table 5). Lots 3 and 4 showed variations in vigor as the temperature increased; at $25^{\circ} \mathrm{C}$ the RPEPI of these lots was higher than at $20^{\circ}$ $\mathrm{C}$, but at $30^{\circ} \mathrm{C}$ both presented low vigor (Table 5).
However, the RPEPI was not related to the emergence of seedlings and therefore it was not an efficient method to classify the vigor of chia seed lots. Similar results were obtained by Machado et al. (2012) in millet seeds and Coimbra et al. (2009) in sweet corn seeds.

Table 5. Root protrusion emission precocity index (RPEPI) in five lots of chia seeds at 20,25 , and $30{ }^{\circ} \mathrm{C}$.

\begin{tabular}{cccc}
\hline \multirow{2}{*}{ Lots } & 20 & 25 & 30 \\
\cline { 2 - 4 } & & $\left({ }^{\circ} \mathrm{C}\right)$ & $3.91 \mathrm{~b}$ \\
2 & $1.91 \mathrm{~b}$ & $2.54 \mathrm{~b}$ & $4.60 \mathrm{a}$ \\
3 & $2.61 \mathrm{a}$ & $3.26 \mathrm{a}$ & $3.22 \mathrm{c}$ \\
4 & $1.89 \mathrm{~b}$ & $2.87 \mathrm{a}$ & $3.27 \mathrm{c}$ \\
5 & $1.67 \mathrm{~b}$ & $2.56 \mathrm{~b}$ & $2.59 \mathrm{~d}$ \\
\hline $\mathrm{F}$ & $0.38 \mathrm{c}$ & $1.93 \mathrm{c}$ & $33.36^{*}$ \\
\hline $\mathrm{CV} \%$ & $16.15^{*}$ & $7.74^{*}$ & 7.50 \\
\hline
\end{tabular}

${ }^{n s}$ not significant at $5 \%$ probability. * significant by $\mathrm{F}$ test. Means followed by the same letter in the column do not differ by Scott-Knott's test at 5\% probability. CV - coefficient of variation.

\section{CONCLUSION}

The root protrusion test has sufficient sensitivity to detect differences in vigor between lots of chia seeds and should be conducted for $30 \mathrm{~h}$ at 25 ${ }^{\circ} \mathrm{C}$.

\section{REFERENCES}

ALBUQUERQUE, K. S. et al. Alterações fisiológicas e bioquímicas durante embebição de sementes de sucupira-preta (Bowdichia virgilioides Kunth.). Revista Brasileira de Sementes, v. 31, n. 1, p. 12-19, 2009.

AYERZA, R.; COATES, W. Protein content, oil content and fatty acid profiles as potential criteria to determine the origin of commercially grown chia (Salvia hispanica L.). Industrial Crops and Products, v. 34, n. 2, p. 1366-1371, 2011.

BEWLEY, J. D.; BLACK, M. Physiology and biochemistry of seed in relation to germination: viability, dormancy and environmental control. New York: Springer-Verlag, 1982. 375 p.

BEWLEY, J. D.; BLACK, J. M. Seeds: physiology of development and germination. 2. ed. New York: Plenum Press. 1994. 445 p.

BRASIL. Ministério da Agricultura, Pecuária e Abastecimento. Regras para análise de sementes. Ministério da Agricultura, Pecuária e Abastecimento. Secretaria de Defesa Agropecuária. Brasília: MAPA/ ACS, 2009. 395 p.

CARVAlHO, N. M.; NAKAGAWA, J. Sementes: ciência, tecnologia e produção. 5. ed. Jaboticabal,
SP: Funep, 2012. 590 p.

COIMBRA, R. A. et al. Teste de vigor utilizado na avaliação da qualidade fisiológica de lotes de sementes de milho-doce (sh2). Ciência Rural, v. 39, n. 9 , p. $2402-2408,2009$.

CUSTÓDIO, C. C. Testes rápidos para avaliação do vigor de sementes: uma revisão. Colloquium Agrariae, v. 1, n. 1, p. 29-41, 2005.

HOFS, A. et al. Efeito da qualidade fisiológica das sementes e da densidade de semeadura sobre o rendimento de grãos e qualidade industrial em arroz. Revista Brasileira de Sementes, v. 26, n. 2, p. 5462, 2004.

LEAL, C. C. P. et al. Validação de testes de vigor para sementes de rúcula (Eruca sativa L.). Revista Brasileira de Biociências, v. 10, n. 3, p. 421-424, 2012.

MACHADO, C. G. et al. Precocidade na emissão da raiz primária para avaliação do vigor de sementes de milheto. Semina: Ciências Agrárias, v. 33, n. 2, p. 499-506, 2012.

MAGUIRE, J. D. Speed of germination-aid in relation evaluation for seedling emergence vigor. Crop Science, v. 2, n. 2, p. 176-177, 1962.

MARCOS-FILHO, J. Fisiologia de sementes de plantas cultivadas. 2. ed. Londrina, PR: ABRATES, 2015. $659 \mathrm{p}$

MARTINELLI-SENEME, A. et al. Avaliação do vigor de sementes peliculizadas de tomate. Revista Brasileira de Sementes, v. 26, n. 2, p. 1-6, 2004. 
MARTINS, C. C. et al. Comparação entre métodos para avaliação do vigor de lotes de sementes de couve-brócolos (Brassica oleracea L. var. italica PLENK). Revista Brasileira de Sementes, v. 24, n. 2, p. 96-101, 2002.

MIGLIAVACCA, R. A. et al. O cultivo da chia no Brasil: futuro e perspectivas. Journal of Agronomic Sciences, v. 3, Sup., p. 161-179, 2014.

NONOGAKI, H. Seed germination: the biochemical and molecular mechanisms. Breeding Science, v. 56, n. 1, p. 93-105, 2006.

PEREIRA, F. R. S. et al. Qualidade fisiológica de sementes de milho tratadas com molibdênio. Revista Brasileira de Sementes, v. 34, n. 3, p. 450-456, 2012.

POSSENTI, J. C. et al. Influência da temperatura e do substrato para a germinação de sementes de chia. Científica, v. 44, n. 2, p. 235-238, 2016.

ROCHA, T. G. F. et al. Vigor de sementes de moringa pelo teste de emissão da raiz primária. Tecnologia \& Ciência Agropecuária, v. 10, n. 5, p. 63-68, 2016.

SANDOVAL-OLIVEROS, M. R.; PAREDESLÓPES, O. Isolation and characterization of proteins from chia seeds (Salvia hispanica L.). Journal of Agricultural and Food Chemistry, v. 61, n. 1, p. 193-201, 2013.

STEFANELLO, R. et al. Germinação e vigor de sementes de chia (Salvia hispanica L. - Lamiaceae) sob diferentes temperaturas e condições de luz. Revista Brasileira de Plantas Medicinais, v. 17, $\mathrm{n}$. 4, p. 1182-1186, 2015.

TOLEDO, F. F. et al. Vigor de semente de milho (Zea mays L.) avaliado pela precocidade de emissão da raiz primária. Scientia Agrícola, v. 6, n. 1, p. 191 $-196,1999$.

WRASSE, C. F. et al. Testes de vigor para sementes de arroz e sua relação com o comportamento de hidratação de sementes e a emergência de plântulas. Científica, v. 37, n. 2, p. 107-114, 2009. 